\title{
PENGEMBANGAN GAME BASED LEARNING BERBASIS PENDEKATAN SAINTIFIK PADA SISWA KELAS IV SEKOLAH DASAR
}

\author{
Mochammad Arbayu Maulidina ${ }^{1}$, Susilaningsih ${ }^{2}$, Zainul Abidin ${ }^{3}$ \\ Jurusan Teknologi Pendidikan, Fakultas Ilmu Pendidikan, Universitas Negeri Malang \\ Jl. Semarang 5 Malang 65145 - 0341-574700 \\ E-mail:m.arbayu@gmail.com
}

\begin{abstract}
ABSTRAK
Berkembangnya teknologi selalubanyak inovasi danmengalami kemjuan yang sangat cepat. Banyak orang dewasa memanfaatkannyadalam dunia pekerjaandan anak-anak memanfaatkannya untuk bermain game/permainan.Bermain adalah aktivitas yang paling disukai oleh anak, selain bermain anak-anak perlu mendapatkan proses pembelajaran yang biasa dilakukan di sekolah. Selalu dibutuhkan invoasi barudan butuh menggunakan cara khusus dalam mengajak anak untuk belajar. Salah satu inovasinya adalah dengan dikembangkannya aplikasi game based learning berbasis pendekatan saintifik. Tujuan dari pengembangan aplikasi ini adalah untuk menghasilkan aplikasi atau media pembelajatan yang valid yang di terapkan di siswa kelas iv SDN Urangagung Sidoarjo, Metode penelitian yang digunakan adalah dengan menggunakan metode pengembangan yang telah dimodifikasi menurut Sugiyono. Langkah-langkah penelitian yaitu Potensi dan masalah, Pengumpulan data, Validasi desain, Desain produk, Revisi Desain, Ujicoba Produk, Revisi Produk, Produk Akhir. Berdasarkan hasil penelitian aplikasi game based learning dinyatakan valid dan layak digunakan dalam pembelajaran.
\end{abstract}

Kata kunci : Game Based Learning, Pendekatan Saintifik, Tematik, Kurikulum 2013

mencari kesenangan. Selain bermain anak-

\section{PENDAHULUAN}

Perkembangan teknologi selalu banyak inovasi danmengalami kemajuan yang sangat cepat. Banyak aktivitas manusia yang dibantu oleh alat-alat canggih. Alat-alat canggih tidak hanya digunakan dan dimanfaatkan oleh orang dewasa namun juga anak-anak. Semua kalangan merasakan manfaat yang besar dengan adanya alat-alat canggih. Orang dewasa memanfaatkan alat canggih dalam dunia kerja, dan anak-anak memanfaatkannya untuk bermaingame/permainan.

Bermain adalahkegiatan yang sangat disukai oleh anak, mapun orang dewasa. Menurut Hans Daeng dalam (Andang Ismail, 2009 :17) bermain merupakan bagian mutlak dari kehidupan anak dan permainan merupakan bagian integral dariproses pembentukan kepribadian anak. Melalui Permainan yang mendidik akan menciptakan anak-anak berkarakter baik. Masa anak-anak adalah masa-masa yang sangat menyenangkan, wajar jika aktivitas mereka bermain untuk anak pun juga mendapatkan proses pembelajaran yang biasa dilakukan disekolah. Bagaimanamereka dapat mengenal segala sesuatu dan juga mendapatkan ilmu yang sangatmembantu untuk masa depan mereka. Namun dibutuhkan cara-cara yang cukup menarik untuk mengajak anak-anak untuk belajar sesuai dengan karakteristik anak-anak yang cenderung suka bermain dan belum bisa jauh dari dunia kongkrit.

Banyak hal tidak kongkrit atau imajinatif yang sulit dipikirkan pebelajar dapat di presentasikan melalui simulasi multimedia pembelajaran interaktif. Hal ini tentu saja akan lebih menyederhanakan jalan pikiran pebelajar dalam memahaminya (Darojat, 2016).

Permainan digital merupakan permainan yang sudah di audio visualkan, dalam bentuk aplikasi. Permainan digital inilah yang kita sebut sekarang sebagai game. Permainan digital atau game ini sering kita temuidi perangkat - perangkat tertentu seperti, televisi, komputer, laptop, smartphone dan lain sebagainya. Ada 
banyak sekali jenis permainan digital ataugame dan berbagai tujuan, salah satunya adalah game edukasi yang memiliki tujuan untuk pembelajaran. Di era modern seperti sekarang bukan hal yang tidak mungkin untuk memanfaatkan game digital sebagai media pembelajaran dalam kegiatan mengajar atau biasa disebut dengan game based learning atau pembelajaran berbasis permainan.

Pendekatan saintifik merupakan kerangka ilmiah pembelajaran yang ditetapkan oleh kurikulum 2013. Dalam pendekatan ini pebelajarbukan dijadikan sebagai objek pembelajaran, tetapi dijadikan sebagai subjek pembelajaran, pembelajar hanya sebagai pendamping atau fasilitator dan motivator saja. Pembelajaran dengan pendekatan saintifik adalah pembelajaan yang di rancang sedemikian rupa agar pebelajar secara aktif membangun konsep, hukum atau prinsip melalui tahapan-tahapan mengamati, merumuskan masalah, mengajukan atau merumuskan hipotesis, mengumpulkan informasi dan data dengan berbagai teknik, menganalisa data, menarik kesimpulan dan mengomunikasikan konsep, hukum atau prinsip yang ditemukan.

(2017) Teori situated learning mendeskripsikan bagaimana manusia berpikir dan bertindakdengan lebih baik dalam suatu konteks,yaitu dengan memberikan kesempatan bagipebelajar untuk mengintegrasikan informasi mereka dari berbagai sumber.

Oleh karena itu kondisi pembelajaran yang terciptadiharapkan bisa diarahkan untuk mendorong pebelajar dalam mencari informasi dari berbagai sumber melalui observasi, dan bukan hanya diberi tahu.

Dengan adanya game based learning berbasis pendekatan saintifiksebagai media pembelajaran diharapkan pebelajar belajar sambil bermain sehingga mereka bisa lebih merasa senang dan lebih semangat dalam berlajar.

\section{Game Based Learning}

Games based learning adalah jenis serious game yang dirancang untuk tujuan tertentu dalam pembelajaran. Menurut Prasetya, dkk (2013) Game based learning merupakan bentuk pembelajaran berpusat pada pebelajar yang menggunakan game elektronik atau digital untuk tujuan pembelajaran. Proses pembelajaran berbasis game memanfaatkan permainan digital sebagai media untuk menyampaikan pembelajaran, meningkatkan kemampuan pemahaman dan pengetahuan, penilaian atau evaluasi mengenai materi suatu disiplin ilmu pengetahuan.

Dalam menentukan ketepatan media yang akan dipersiapkan dan digunakan melalui proses pengambilan keputusan adalah berhubungan dengan kemampuan yang dimiliki oleh media termasuk kelebihan dari karakteristik media yang bersangkutan dihubungkan dengan berbagai komponen pembelajara (Zainul : 2016). Pengembangan game based learningbisamendatangkan lingkungan yangmemotivasi, menyenangkan, dan mingkatkan kreativitas. Pendekatan game pembelajaran mampumenstimulus emosional, intelektual, dan psikomotorik anak (Prensky, 2010).Oleh karena itu game based learning bisa menjadi solusi yang menarik untuk pebelajar. Pengembangan aplikasi pembelajaran sudah banyak diterapkan. Namun sebagian besar penelitian menghasilkan media pembelajaran untuk membaca, menulis dan berhitung yang sifatnya fomal dan terkesan memanfaatkan media pembelajaran yang sudah umum digunakan.

\section{Pendekatan Saintifik}

Pendekatan saintifik, pendekatan yang wajib dilaksanakandalam pembelajaran disekolah, baik sekolah dasar ataupun sekolah menegah berdasarkan aturan kurikulum 2013.

Daryanto

mengungkapkan, pembelajaran dengan pendekatan saintifik merupakan proses 
pembelajaran yang didesain sedemikian rupa agar pebelajar secara aktif mengkonstruksi konsep, hukum atau prinsip melalui tahapantahapan mengamati, merumuskan masalah, mengajukan atau merumuskan hipotesis, mengumpulkan data dengan berbagai teknik, menganalisis data, menarik kesimpulan dan mengkomunikasikan konsep, hukum atau prinsip yang ditemukan.

Pendekatan saintifik memiliki beberapa tahapan yang meliputi :Mengamati, yaitu pebelajar diharapkan dapat menyaksikan tentang apa yang di sajikan pembelajar, misalnya multimedia yang terkait materi, pembeajar juga bisa menampilkan gambar-gambar yang juga terkait dengan materi. Pengamatan dapat dilakukan saat pembelajar melakukan simulasi. Menanya, yaitu pebelajar mengajukan pertanyaan tentang hal-hal yang kurangdimengerti dari apa yang dilihat untuk mendapat sumber tambahan tentang apa yang diamati. Mengumpulkan Infomasi, yaitu pebelajar selanjutnya mengumpulkan informasi dan informasi tersebut untuk menjawab pertanyaan yang sudah dibuat, informasi tersebut dapat diperoleh dari brbagai sumber belajar seperti buku, studi perpustakaan, dan internet. Mengolah Infomasi, yaitu pebelajarbersama kelompoknya bebagi tugas untuk mengasosiasikan atau megolah informasi yang sudah di dapat yang bertujuan untuk menjawab pertanyaan yang sudah dirumuskan. Dan Mengkomunikasikan, yaitu pebelajar di harapkan mampu mengkomunikasiskan bersama kelompok lain tentang informasi apa yang sudah di olah dalam kelompoknya.

\section{Karakteristik Siswa Sekolah Dasar}

Karakteristik utama siswa sekolah dasar adalah mereka punya perbedaan tiap pribadi dalam banyak segi bidang diantaranya, perbedaan dalam intelejensi, kognitif, bahasa, perkembangan pribadi dan perkembangan fisik.
Dengan karakteristik pebelajar yang telah diuraikan diatas, pembelajar dituntutagar bisa mengemas perencanaan dan pengalaman belajar yang akan diberikan kepada pebelajar dengan baik. Menyampaikan hal-hal yang terdapatpada lingkungan sekitar kehidupan pebelajar sehari-hari sehingga materi yang dipelajari lebih kongkrit dan lebih bermakna .

\section{METODE PENELITIAN}

Metode Penelitian yang digunakan adalah metode Research and Development (Peneletian dan Pengembangan).Adapun prosedur yang akan dilaksanakan oleh peneliti dengan memodifikasi model Sugiyono (2013:298) yang meliputi sepuluh kegiatan kegiatan yaitu : Potensi dan Masalah, Pengumpulan Data, Desain Produk, Validasi Desain, Revisi Desain Produk, Ujicoba Produk, Revisi Ujicoba Produk, Uji Pemakaian, Revisi Produk, dan Produk Akhir. namun penelitian dan pengembangan game based learning ini hanya menggunakan delapan langkah penelitian dikarenakan pertimbangan biaya dan waktu yang ada. Berikut adalah langkah - lahkah penelitian model sugiyono :

\section{Potensi dan Masalah}

Langkah awal yang dilakukan oleh peneliti untuk menentukan potensi dan masalah dalam melakukan penelitian pengembangan ini yaitu mengkaji teori yang relevan dengan penelitian.

\section{Mengumpulkan Informasi}

Pada tahap pengumpulan informasi ini, peneliti mewawancarai siswa, guru, dan kepala sekolah. Dari hasil informasi yang didapat, multimedia masih belum dimanfaatkan secara maksismal oleh pembelajar untuk mengajar. Khususnya pada Tema 5 pahlawanku, guru masih kesulitan dalam memberikan contoh nyata untuk siswa. Selain itu, Peneliti juga menganalisis kemampuan seperti: memperkirakan dana, sarana dan prasarana,tenaga dan waktu yang dibutuhkan untuk penelitian 
pengembangan.

\section{Desain Produk}

Pada Tahap ini, Peneliti membuat desain / rancangan pengembangan yang akan dikembangkan berupa game based learning. Sebelum memasuki tahap pembuatan game based learning, dibutuhkan suatu rancangan sebagai rujukan bagi pengembang agar tahap pengembangan tidak melenceng dengan apa yang direncanakan.

Mediayang dikembangkan adalah media pembelajaran game based learning, maka model yang dikembangkan adalah model educational game, yang dalam proses perancangannya meliputi pembuatan flowchart, storyboard, dan rancangan antarmuka pemakai

a. Flowchart

Game based learning memiliki langkahlangkah yang dikerjakan oleh pengguna. Langkah-langkah tersebut merupakan alur kerja dari game yang disebut flowchart.Flowchartakan menunjukkan gambaran secara umumdari aliran setiap kemungkinan aktifitas dalam game based learning dengan menggunakan simbolsimbol tertentu.

b. Storyboard

Setelah flowchart dirancang maka rancangan tersebut di olah ke dalam storyboard. Fungsinya adalah untuk mendeskripsikan cerita dan komponen dalam game based learning dalam setiap scene yang telah dibuat dalam flowchart. Storyboard merupakan penjabaran proses pembelajaran yang sudah didesain dan berisi informasi pembelajaran dan prosedur serta petunjuk pembalajaran. Storyboardmemperlihatkanhal-hal yang harus dilakukan pebelajar selama mengikuti pembelajaran dengan game yang dikembangkan.

c. Rancangan antarmuka / User interface Antarmuka / User Interface pemakai game based learning yang akan dikembangkan merujuk kepada storyboard yang telah dibuat sebelumnya. Rancangan antarmuka / User Interface merupakan halaman- halaman bagian tampilan dalam game based learning yang telah dibuat dalam bentuk gambar.

4. Validasi Desain

Setelah membuat Produk kemudian peneliti melakukan validasi media menggunakan teknik penyebaran angket dengan melibatkan para ahli yaitu Ahli media serta Ahli Materi.

\section{Revisi Desain}

Setelah melakukan validasi menurut ahli media dan ahli materi, peneliti akan melakukan perbaikan jika ada kekurangan pada produk yang dikembangkan. Revisi ini diperoleh menurut saran dari ahli media serta ahli materi.

\section{Uji coba Produk}

Setelah melakukan revisi desain produk, peneliti akan melakukan ujicoba di dalam pembelajaran dikelas untuk mengetahui kelayakan game based learning yang dikembangkan ini.

7. Revisi Ujicoba Produk

Dari hasil uji coba produk, peneliti akan melakukan perbaikan menurut saran siswa dan guru jika ada kekurangan pada produk game based learning yang dikembangkan ini. Saran dan komentar diperoleh dari instrumen yang diberikan kepada pebelajar. Kemudian akan dilakukan perbaikan media melalui saran yang telah terkumpul.

\section{Produk Akhir}

Hasil akhir media pembelajaran yang dikembangkan berdasakan hasil dari revisi, validasi dan uji akandisimpan ke dalam $C D$ agar mudah penggunaan dan penyimpananya. CD akan dikemas menarik jika produk akhir telah dinyatakan layak digunakan.

\section{HASIL DAN PEMBAHASAN}

Tabel 1. Hasil Validasi Ahli

\begin{tabular}{|l|c|c|}
\hline No & Validator & Presentase \\
\hline 1 & Ahli Media & $\mathbf{9 7 , 6 3 \%}$ \\
\hline 2 & Ahli Materi & $\mathbf{9 6 , 2 9 \%}$ \\
\hline
\end{tabular}


Berdasarkan Pengolahan data ahli media yang tersedia pada tabel tersebut, Secara keseluruhan dapat diperoleh hasil 97,63\%. Berdasarkan hasil olah data dan kriteria yang telah ditentukan diketahui bahwa game based learning yang dikembangkan termasuk kedalam kriteria Valid atau Layak dan dapat dimanfaatkan dalam pembelajaran dengan beberapa saran dari ahli media yaitu perbaikan penataan visual game based learning dan packaging.

Berdasarkan olah data ahli materiyang tersedia pada tabel tersebut tersebut, secara keseluruhan dapat diperoleh hasil 96,29\%. Berdasarkan hasil pengolahan data dan kriteria yang telah ditentukan,diketahui bahwa materi yang terdapat pada game based learning termasuk dalam kategori Validatau Layak dan dapat dimanfaatkan dalam pembelajaran dengan beberapa saran dari ahli materi yaitu Mempersingkat Materi yang terdapat pada Game based Learning.

Tabel 2.Hasil Uji Coba Perseorangan, Kelompok Kecil, Lapangan, dan Tes Hasil Belajar

\begin{tabular}{|c|c|c|}
\hline No & Uji Coba & Persentase \\
\hline 1 & Perseorangan & $\mathbf{8 9 , 5 \%}$ \\
\hline 2 & Kelompok Kecil & $\mathbf{8 9 , 2 \%}$ \\
\hline 3 & Lapangan & $\mathbf{8 9 , 9 5 \%}$ \\
\hline 4 & Tes Hasil Belajar & $\mathbf{7 7 , 2 7 \%}$ \\
\hline
\end{tabular}

Berdasarkan hasil olah data pada uji coba perseorangan, secara keseluruhan dapat diperoleh hasil $89,5 \%$. Berdasarkan hasil pengolahan data dan kriteria yang telah ditentukan,diketahui bahwa game based learning termasuk dalam kategori Validatau Layak dan dapat dimanfaatkan dalam pembelajarandengan beberapa saran yaitu menambahkan level pada game based learning.

Berdasarkan hasil olah data pada uji coba perseorangan tersebut, secara keseluruhan dapat diperoleh hasil 89,2\%. Berdasarkan hasil pengolahan data dan kriteria yang telah ditentukan,diketahui bahwa game based learning termasuk dalam kategori Validatau Layak dan dapat dimanfaatkan dalam pembelajaran dengan beberapa saran yaitu menambahkan level pada game based learning.

Berdasarkan hasilolah data pada uji coba lapangan, secara keseluruhan dapat diperoleh hasil $89,95 \%$. Berdasarkan hasil pengolahan data dan kriteria yang telah ditentukan,diketahui bahwa game based learning termasuk dalam kategori Validatau Layak dan dapat dimanfaatkan dalam pembelajaran dengan beberapa saran yaitu menambahkan level pada game based learning.

Berdasarkan hasil olah data ketuntasan belajar siswa di lapangan, secara keseluruhan hasil post test dapat diperoleh hasil presentase sebesar 77,27\%. Berdasarkan interpretasi data, termasuk dalam kategori A dengan persentase 76\%$100 \%$ maka dapat disimpulkan bahwa game based learningtermasuk dalam kategoriefektif.

Revisi Produk merupakan hasil kesimpulan yang berasal dari hasil analisa data dari ahli media, ahli materi, dan uji coba pada audiens tentang game yang divalidasikan agar produk tersebut lebih sempurna dan lebih efektif untuk kegiatan pembelajaran. Revisi Produk tersebut meliputi:

\section{1. Tanggapan Ahli Media}

Berdasarkan instrumen yang berasal dari ahli media, terdapat Saran dan Kritik yakni, Secara Umum Media valid dan dapat dilanjutkan ke tahap berikutnya, dan sedikit masukan yaitu penataan visual pada gamed based learning dan packaging.

2. 2. Tanggapan Ahli Materi

Berdasarkan instrumen yang berasal dari ahli materi, terdapat saran dan kritik yakni, Media sudah cukup baik dan menarik namun sebaiknya pada petunjuk pemanfaatan tercantum pembelajaran ke berapa dan lebih mempersingkat materi yang ada dalam game based learning.

3. 3. Tanggapan Audiens

Berdasrkan instrumen yang berasal dari siswa saat uji coba lapangan ada beberapa 
Kritik dan saran dari audiens yakni penambahan level pada game based learning yang di rasa kurang banyak oleh siswa.

\section{KESIMPULAN}

Game based Learning adalah metode pembelajaran yang memanfaatkan pemainan/game yang telah dirancang khusus untuk membantu proses pembelajaran. Pengembangan game based learning mampu menghadirkan lingkungan yang memotivasi, menyenangkan dan mingkatkan kreativitas. Pendekatan game pembelajaran mampu menstimulus intelektual, emosional, dan psikomotorik anak

Pendekatan saintifik merupakan pendekatan yang wajib dilaksanakan pada pembelajaran disekolah, baik sekolah dasar atau sekolah menegah berdasarkan aturan kurikulum 2013. Pembelajaran dengan melaksanakanpendekatan saintifik merupakan proses pembelajaran yang didesain sedemikian rupa agar pebelajar secara aktif mengkonstruksi konsep, hukum atau prinsip melalui tahapantahapan mengamati, merumuskan masalah, mengajukan atau merumuskan hipotesis, mengumpulkan data dengan berbagai teknik, menganalisis data, menarik kesimpulan dan mengkomunikasikan konsep.

Mengemas sebuah pembelajaran dalam game based learning dengan menggunakan pendekatan saintifik merupakan terobosan baru metode pembelajaran untuk pebelajar. Disisi lain aplikasi ini juga sangat membantu pembelajar dalam menyampaikan materi dikelas dan membuat pebelajar lebih termotivasi dan semangat dalam belajar seperti yang ditemukan saat peneitian di lapangan.

\section{DAFTAR PUSTAKA}

Abidin, Zainul. (2016). Penerapan Pemilihan Media Pembelajaran. EDCOMTECH, 1 (1), 9-20.

Darojat, Achmad. (2016).Pengembangan Multimedia Pembelajaran Intraktif Pada Mata Pelajaran Ilmu Pengetahuan Alam Untuk Siswa Kelas VII SMP.JINOTEP, 2(2), 297-301.

Daryanto, 2014. Pembelajran Tematik, Terpadu, Terintegrasi (Kurikulum 2013). Jogjakarta: Gava Media.

Ismail Andang. 2009. Education Games. Yogyakarta: Pro U Media.

Prasetiyo, T,K., Setyosari ,P., Sihkabuden. (2017). Pengembangan Media Augmented Reality Untuk Program

Keahlian Gambar Bangun di Sekolah Menengah Kejuruan. JINOTEP, 1 (4), 37-46.

Prasetya, D,D., Sakti, W., Patmanthara, S. (2013). Digital Game-Based Learning Untuk Anak Usia Dini. TEKNO, 2 (20), 45-50.

Prensky, M. 2001. Digital Game-Based Learning. USA: McGraw Hill.

Sugiyono. 2009. Metode Penelitian kualitatif, kuantitatif, dan $R \& D$. Bandung 